\title{
COMPLEX SULPHIDE-BARITE ORE LEACHING IN FERRIC CHLORIDE SOLUTION
}

\author{
Miroslav Sokić ${ }^{1 *}$, Vladislav Matković ${ }^{1}$, Branislav Marković ${ }^{1}$, Vaso \\ Manojlović ${ }^{1}$, Nada Štrbac ${ }^{2}$, Dragana Živković ${ }^{2}$, Željko Kamberović ${ }^{3}$ \\ ${ }^{1}$ Institute for Technology of Nuclear and Other Mineral Raw Materials, \\ Bulevar Franša d'Eperea 86, 11000 Belgrade, Serbia \\ ${ }^{2}$ Technical Faculty, University of Belgrade, Vojske Jugoslavije 12, \\ 19210 Bor, Serbia \\ ${ }^{3}$ Faculty of Technology and Metallurgy, University of Belgrade, Karnegijeva 4, \\ 11120 Belgrade, Serbia
}

Received 24.02.2016

Accepted 11.03.2016

\begin{abstract}
The results of research on the leaching process of complex sulphide-barite ore were presented in this paper. The leaching process was carried out in a laboratory autoclave by ferric chloride solution. Considering that those minerals are represented in complex structural-textural relationships, it is not possible to extract lead, zinc and copper minerals from ore by flotation methods. The obtained results confirmed possibility of the ore processing directly, by chemical methods. The effect of temperature, time and oxygen partial pressure on the lead, zinc and copper dissolution was studied. The maximal leaching degree was achieved at $100{ }^{\circ} \mathrm{C}$ and amount of $91.5 \%$ for $\mathrm{Pb}, 96.1 \%$ for $\mathrm{Zn}$ and $60.7 \%$ for $\mathrm{Cu}$ ). Leaching at temperatures above $100^{\circ} \mathrm{C}$ is impractical.

Key words: sulphide-barite ore, high pressure leaching, ferric chloride
\end{abstract}

\section{Introduction}

Non-ferrous metals and iron usually appears in a form of sulphide complex ores. The large deposits of complex ores may contain chalcopyrite, sphalerite, galena and pyrite in disseminated form with complex mineralogical composition and fine grained structures. These minerals are generally separated from each other by flotation and treated by conventional pyrometallurgical processes. Sometimes, when it is difficult to

* Corresponding author: Miroslav Sokić, m.sokic@itnms.ac.rs 
prepare flotation concentrates of the individual minerals, then it is easier to prepare bulk concentrates [1].

Hydrometallurgical processes offer great potential for treating complex sulphide concentrates, resulting in increased metal recoveries and reduced air pollution hazards. Ferric and cupric ions, bacteria, oxygen, and other oxidants have been used as leaching agents of sulphide in sulphate and chloride media under atmospheric or pressure leaching conditions [2-20].

Ferric chloride is one of the most important oxidative agents in leaching process. The oxidation potential of ferric chloride leaching system results in elemental sulphur as one of the major by-products, a form generally more acceptable environmentally than the sulphur dioxide from pyrometallurgy. The leaching of metal sulphide minerals in chloride media is a subject of interest and many articles have been published [12-18]. This studied indicated that the ferric chloride solutions could rapidly, but unselectively leach valuable metals such as copper, zinc and lead from sulphide minerals, leaving the bulk of the pyrite and sulphur. The reaction mechanism of complex copper-zinc-lead sulphide concentrate leaching in ferric chloride solution may be described by (1)

$$
\mathrm{MeS}+2 \mathrm{FeCl}_{3}=\mathrm{MeCl}_{2}+2 \mathrm{FeCl}_{2}+\mathrm{S}^{\circ}
$$

where $\mathrm{Me}$ is $\mathrm{Cu}, \mathrm{Zn}$ or $\mathrm{Pb}$. Oxidizing agents such $\mathrm{O}_{2}$ or $\mathrm{H}_{2} \mathrm{O}_{2}$ may be used for oxidation of ferrous ions formed through reaction (1) $[19,20]$.

The leaching of sulphides by ferric chloride is governed by parabolic kinetics caused by progressive formation of a compact layer of elemental sulphur on the solid/liquid interface. The leaching process is slow under normal temperature and pressure. Previous results showed that after an initially rapid reaction period the dissolution rate decreases and reaches a steady state. During this steady period the development of a porous layer of elemental sulphur at the surface limits the reaction.

Besides the genesis of sulphide minerals and reaction conditions, the kinetic parameters of leaching are also dependent on the morphology and compactness of the sulphur layer [13]. The determination of the optimal leaching rate is thus the major object in this study, because the values of leaching rate published in various papers and especially those obtained by investigations with natural concentrates exhibit great scatter. Dutrizac [16] observed significant differences $\sim 50 \%$ in leaching rates of eleven chalcopyrites from different localities under various leaching conditions. The scattering results can be mainly attributed to admixtures and impurities as well as to the influence of real structure of the investigated material.

The purpose of presented study is to investigate possibility of complex sulphide ore leaching by ferric chloride solutions in autoclave.

\section{Experiments}

The leaching study was conducted in a five-liter stainless steel autoclave, which enabled maximal working temperature of $250^{\circ} \mathrm{C}$ and pressure of $5.5 \mathrm{MPa}$ (Figure 1). Also, this apparatus provided hermetic conditions, heating at constant temperature, addition of oxygen and mechanical mixing. 


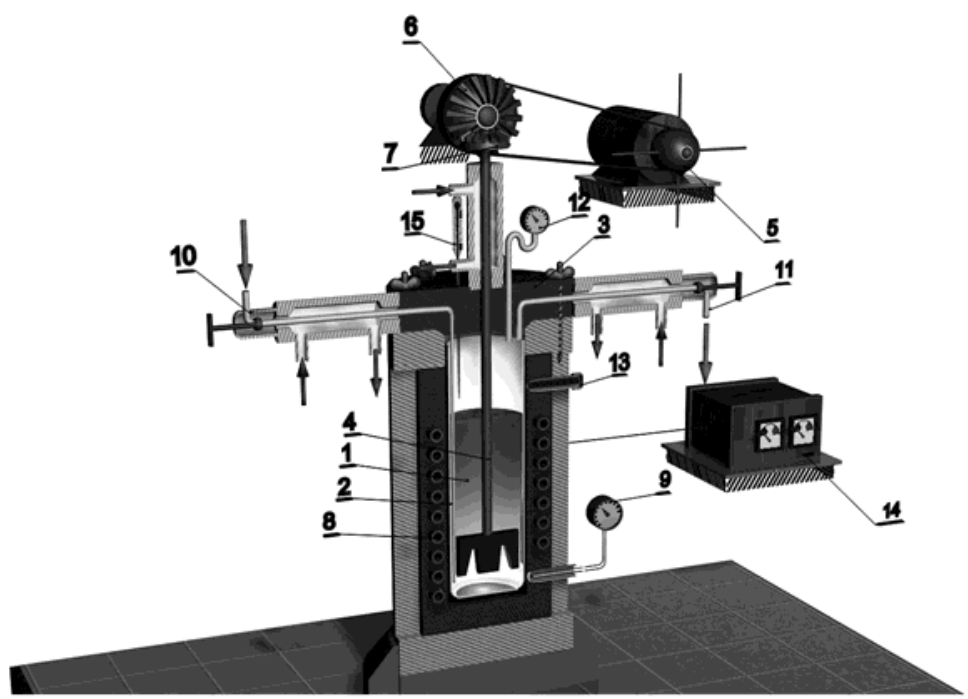

Fig. 1. Schematic of the experimental set up for the high-pressure leaching: 1-chamber, 2-pressure vessel, 3-reactor cover, 4-agitator, 5-electromotor, 6-pulley, 7-gear wheel, 8-heater, 9-thermoragulator, 10 and 11-valves, 12-pressure gauge, 13-pressure relief valve, 14-control panel, 15-thermometer

The calculated volume of $\mathrm{FeCl}_{3}$ and the solid sample of the ore were put into the reactor. Then, the autoclave was closed up, and heated up to the selected temperature. When the temperature was reached, the stirrer was turned on and that moment was taken for beginning of leaching. At the expiration of definite leaching time, the autoclave was turned off, cooled off, opened and solution sample was taken for chemical analysis, which was carried out with AAS (Type PERKIN ELMER). The microscopic tests were carried out using a Carl-Zeiss Jena, JENAPOL-U, reflected- and transmitted-light microscope, and the "OZARIA 2.5" microphotography and quantitative mineralogical analysis program.

\section{Results and discussion}

Characterization of complex sulphide-barite ore

In order to investigate the characteristics of the ore in detail, its chemical and mineral composition and particle size were determined.

For experimental studying of leaching process, the complex sulphide -barite ore from the "Bobija" deposit was used, and comminuted to $75 \mu \mathrm{m}$ particles. Chemical composition of the ore is presented in Table 1.

Table 1. Results of chemical analysis of complex sulphide-barite ore

\begin{tabular}{llllll}
\hline Element & $\mathrm{Fe}$ & $\mathrm{Zn}$ & $\mathrm{Pb}$ & $\mathrm{Cu}$ & $\mathrm{Ba}$ \\
\hline wt. $\%$ & 26.84 & 4.57 & 4.95 & 0.84 & 4.34 \\
\hline
\end{tabular}


The mineralogical researches included both, qualitative and quantitative mineralogical analysis. Correction of quantitative mineralogical analysis was performed using results of chemical analysis. Participation of the most dominant minerals in the ore mas is presented in Table 2.

Table 2. Quantitative mineral composition of the complex sulphide-barite ore

\begin{tabular}{lc}
\hline Minerals & wt. \% \\
\hline Pyrite & 57.52 \\
\hline Sphalerite & 6.82 \\
\hline Galena & 5.72 \\
\hline Tetrahedrite & 1.84 \\
\hline Barite & 7.38 \\
\hline Quartz & 17.90 \\
\hline Others & 2.80 \\
\hline
\end{tabular}

A micrographs of the complex sulphide-barite ore are shown in Figures 2 and 3.

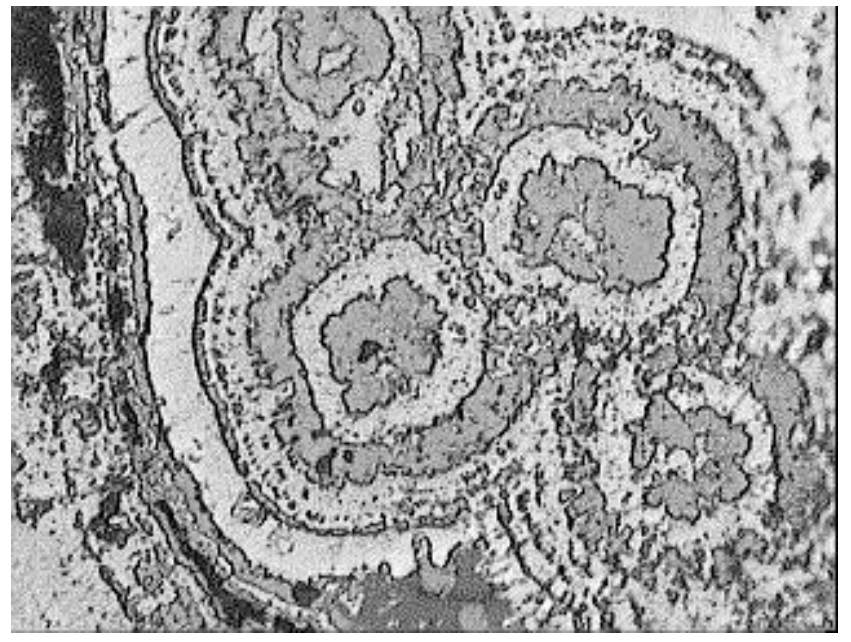

Fig. 2. Compact pyrite ore, with rhythmic colloform textures cemented by galena (gray) and sphalerite (dark gray). [On air, 50×, N II] 


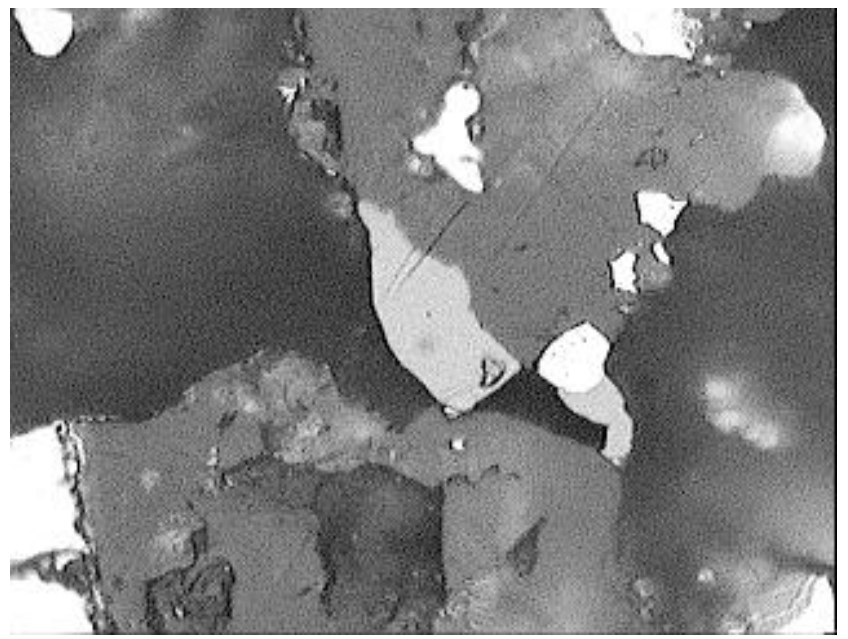

Fig. 3. Aggregates of sphalerite (grey) with tetrahedrite (light grey), galena (white soft) and pyrite (white - hard) in barite base (dark grey). [In oil, 100×, N II]

The obtained micrographs confirm the presence of the following minerals: pyrite, sphalerite, galena, tetrahedrite, barite and quartz. Pyrite, being the most prevailing mineral of the sulphide ore, is intergrown with all other mineral components. Therefore, it is not possible to extract lead, zinc and copper minerals from complex sulphide-barite ore by flotation process.

Leaching tests

The experimental results on determination of leaching parameters of the complex sulphide-barite ore with ferric chloride solution were performed in the temperature range of $80-150^{\circ} \mathrm{C}$, time from 10 up to $150 \mathrm{~min}$, without and with oxygen in an autoclave. In all experiments, the following conditions were constant: phase ratio (S/L) $150 \mathrm{~g}$ ore $/ \mathrm{dm}^{3}, 1.0 \mathrm{~mol} / \mathrm{dm}^{3} \mathrm{Fe}^{3+}$ and stirring rate $400 \mathrm{~min}^{-1}$. Leaching degrees were calculated based on the results of chemical analyses of the solutions and solid rasiduals after leaching.

\section{Effect of temperature and time}

The influence of temperature and time on the leaching degree of lead, zinc and copper, was determined at temperatures of $80,100,120$ and $150{ }^{\circ} \mathrm{C}$ and times of 10,20 , 40, 60, 90 and $120 \mathrm{~min}$, without oxygen, under all other parameters constant. Obtained results are shown in Figures 4-6. 


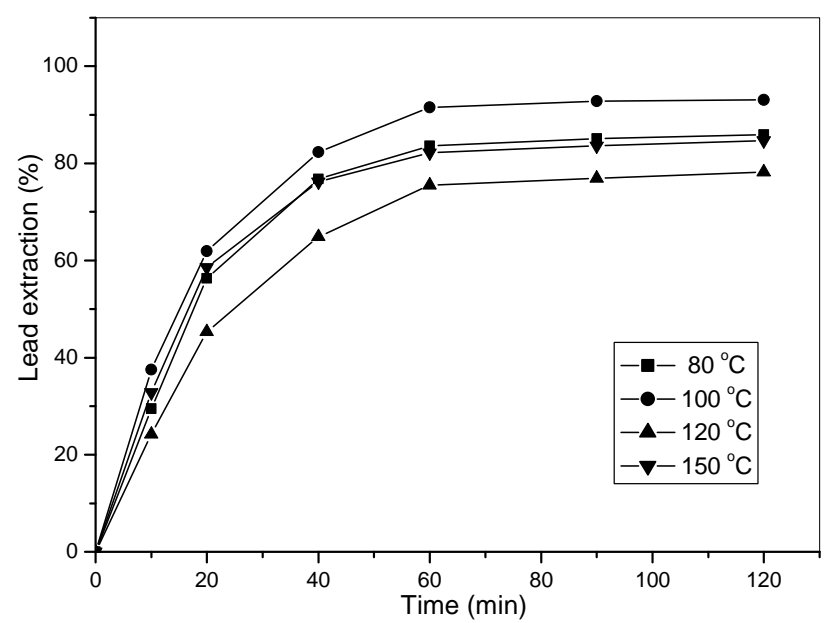

Fig. 4. Temperature and time dependence of the lead leaching

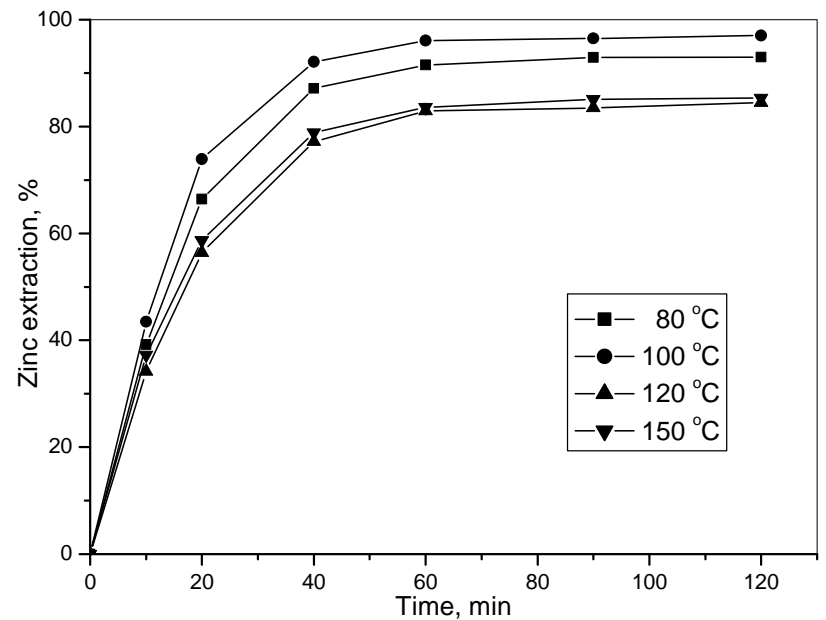

Fig. 5. Temperature and time dependence of the zinc leaching 


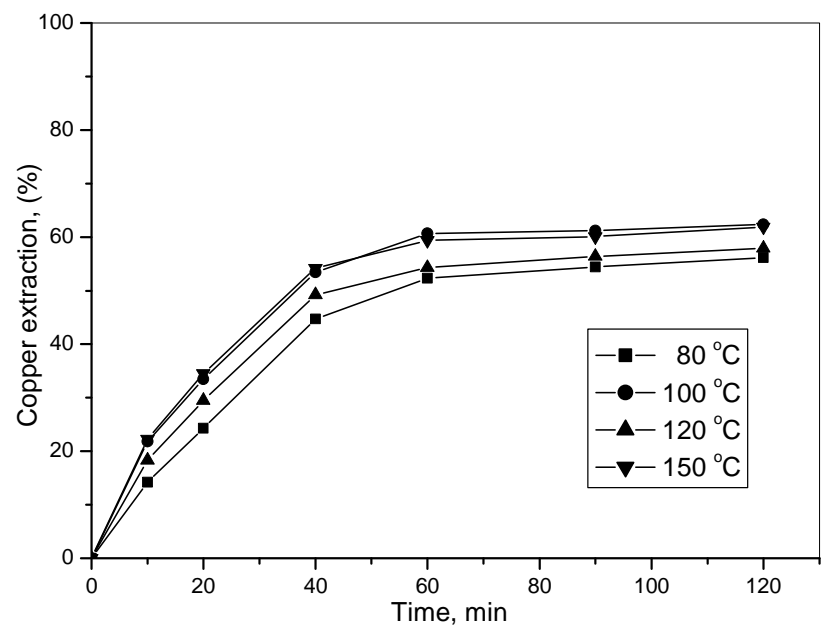

Fig. 6. Temperature and time dependence of the copper leaching

Experimental results (Fig. 4-6) show that the quantity of leached lead, zinc and copper increases when the temperature is increased from 80 to $100{ }^{\circ} \mathrm{C}$, reaches a maximum at $100{ }^{\circ} \mathrm{C}$, thereafter it falls. The reason for leaching decrease at higher temperatures is melting of elemental sulphur, which is formed during the leaching (1) and melts at $119{ }^{\circ} \mathrm{C}$. The molten sulphur generates a viscous layer, surrounding the ore particle, which is the limiting factor for diffusion of leaching reagent. Leaching at temperatures above $100{ }^{\circ} \mathrm{C}$ does not have practical importance.

Investigation of the effect of time on the leaching degree of the particular components showed that lead, zinc and copper extraction increases with increasing the leaching time up to $60 \mathrm{~min}$. After that, the increase in time does not affect significantly the transition of lead, zinc and copper from the ore to the solution. Therefore, it is not necessarily for leaching to last more than $60 \mathrm{~min}$.

\section{Effect of oxygen partial pressure}

The influence of oxygen on the leaching degree was studied by increase of oxygen partial pressure from 0.0 to $1.1 \mathrm{MPa}$. The results obtained at $120{ }^{\circ} \mathrm{C}$ are shown in Table 3.

Table 3. Effect of gaseous oxygen on leaching of lead, zinc and copper

\begin{tabular}{lllllll}
\hline $\mathrm{P}\left(\mathrm{O}_{2}\right)$, & Temp., & {$\left[\mathrm{Fe}^{3+}\right]$,} & \multirow{2}{*}{ Time, min } & \multicolumn{4}{l}{ Leaching degree, $\%$} & \\
\cline { 5 - 7 } $\mathrm{MPa}$ & ${ }^{\circ} \mathrm{C}$ & $\mathrm{mol} / \mathrm{dm}^{3}$ & & $\mathrm{~Pb}$ & $\mathrm{Zn}$ & $\mathrm{Cu}$ \\
\hline 0,0 & 120 & 1.0 & 60 & 75.5 & 83.6 & 54.3 \\
\hline 1,1 & 120 & 1.0 & 60 & 85.6 & 90.7 & 60.3 \\
\hline
\end{tabular}

The injection of oxygen into the autoclave, favorably affects the leaching of lead, zinc and copper (Table 3 ). It can be explained by $\mathrm{Fe}^{2+}$-ions oxidation with oxygen to $\mathrm{Fe}^{3+}$-ions. In this way, the regeneration of $\mathrm{Fe}^{2+}$-ions is achieved, what contributes the leaching. 


\section{Conclusion}

Mineralogical researches of the complex sulphide-barite ore showed the presence of the following minerals: pyrite, sphalerite, galena, tetrahedrite, barite and quartz. The most dominant mineral component is pyrite. The individual minerals present in the ore are very fine-grained and intergrown. The complex structural-textural relationships of the useful minerals do not make possible the classical flotation of this ore, or some other concentration.

The obtained results in this investigation demonstrate the possibility of the sulphide-barite ore processing by leaching with ferric chloride solutions, because of the significant leaching degree achievements, especially for zinc and lead.

The effect of temperature was studied in the temperature range from 80 to $150{ }^{\circ} \mathrm{C}$. The maximal leaching degree was achieved at $100{ }^{\circ} \mathrm{C}(91.5 \% \mathrm{~Pb}, 96.1 \% \mathrm{Zn}$ and $60.7 \% \mathrm{Cu}$ ). Leaching at temperatures above $100{ }^{\circ} \mathrm{C}$ is impractical.

Lead, zinc and copper extraction increases with increasing the leaching time up to $60 \mathrm{~min}$. After that, the increase in time does not affect significantly the leaching of lead, zinc and copper from the complex sulphide-barite ore

The injection of oxygen into the autoclave is favourable, i.e. intensifies dissolution of lead, zinc and copper.

\section{Acknowledgment}

The authors wish to acknowledge the financial support from the Ministry of Education, Science and Technological Development of the Republic of Serbia through the project TR34023.

\section{References}

[1] R. Vračar, L.Šaljić, M.Sokić, V.Matković, S.Radosavljević, Scand. J. Metall., 32 (2003) 289-295.

[2] H.R. Watling, Hydrometallurgy, 140 (2013) 163-180.

[3] Y. Li, N. Kawashima, J. Li, A.P. Chandra, A.R. Gerson, Adv. Colloid Interfac., 197-198 (2013) 1-32.

[4] D.Buttinelli, R. Lavecchia, F. Pochetti, A. Geveci, N. Guresin, Y. Topkaya, Int. J. Miner. Process., 36 (1992) 245-257.

[5] [5] F. Arslan, G. Bulut, M.O. Kangal, K.T. Perek, A. Gul, S. Gurmen, Scand. J. Metall., 33 (2004) 6-14.

[6] A. Akcil, H. Ciftci, Int. J. Miner. Process. 71 (2003) 233-246.

[7] M. Tchoumou, M. Roynette, Leaching of complex sulphide concentrate in acidic cupric chloride solutions, T. Nonferr. Metal. Soc., 17 (2007) 423-428.

[8] M. Sokić, B. Marković, D. Živković, Hydrometallurgy, 95 (2009) 273-279.

[9] M. Sokić, B. Marković, V. Matković, D. Živković, N. Štrbac, J. Stojanović, J. Min. Metall. Sect. B Metall., 48 (2) B (2012) 185-195.

[10] M. Sokić, S. Radosavljević, B. Marković, V. Matković, N. Štrbac, Ž. Kamberović, D. Živković, Metal. Mater. Eng, 20 (2014) 53-60.

[11] B. Marković, M. Sokić, Ž. Kamberović, D. Živković, N. Štrbac, V. Manojlović, Metal. Mater. Eng., 21 (2015) 253-258.

[12] R. Winand, Hydrometallurgy, 27 (1991) 285-316.

[13] H. Majima, Y. Awakura, T. Hirato, T. Tanaka, Can. Metallurg. Q., 24, (1985) 283291. 
[14] J.E. Dutrizac, Hydrometallurgy, 29 (1992) 1-45.

[15] J.E. Dutrizac, Hydrometallurgy, 23 (1990) 153-176.

[16] J.E. Dutrizac, Metall. Trans. B., 13B (1982) 303-309.

[17] K. Tkačova, P. Balaž, B. Mišura, V.E. Vigdergauz, V.A. Chanturiya, Hydrometallurgy, 33 (1993) 291-300.

[18] E. Godočikova, P. Balaž, E. Boldižarova, Hydrometallurgy, 65 (2002) 83-93.

[19] P.C. Rath, R.K. Paramguru, P.K. Jena, Trans. Insti. Min. Metall. C, (1988) 150158.

[20] T. Havlik, M. Škrobian, P. Balaž, R. Kammel, Int. J. Miner. Process., 43 (1995) 6172.

[21] Santos, S.M.C., Machado, R.M., Correia, M.J.N., Reis, M.T.A., Ismael, M.R.C., Carvalho, J.M.R., Miner. Eng., 23 (2010) 606-615.

[22] Rönnholm, M.R., Wärna, J., Salmi, T., Turunen, I., Luoma, M., Chem. Eng. Sci., 54 (1999) 4223-4232. 